\title{
FLOW CYTOMETRY DETERMINATION OF PLOIDY LEVEL IN WINGED BEAN [Psophocarpus tetragonolobus (L.) DC] AND ITS RESPONSE TO COLCHICINE-INDUCED MUTAGENESIS
}

\author{
O. U. UDENSI, E. V. IKPEME AND L. I. EMEAGI
}

(Received 6 February 2017; Revision Accepted 10 April 2017)

\begin{abstract}
Ploidy determination and mutation breeding of crop plants are inseparable twins given that mutation breeding is hinged majorly on polyploidization of crop's chromosome number. The present research was aimed at determining the ploidy level of 20 accessions of winged bean (Psophoscarpus tetragonolobus) using known diploid standard as control and also subjecting two accessions to colchicine mutagenesis. For flow cytometric analysis, approximately $50 \mathrm{~mm}^{2}$ of young fresh intact leaves of 8 weeks post-seedling emergence from the 20 accessions were used. Crude isolation of nuclei was done by chopping the leaf in $1 \mathrm{ml}$ of ice cold buffer from DNA kit (cysteine UV Partec GmbH Germany) using a razor blade. The crude suspension was then filtered through a $30 \mu \mathrm{m}$ pore diameter nylon mesh and stained with 4,6- diaminodino-2-phenylindole (DAPI). Fluorescence intensity of isolated nuclei was measured using a partec PAll flow cytometry equipped with an argon ion laser at $488 \mathrm{~nm}$.For mutation induction, 20 seeds from accessionsTPt26 and TPt154 were soaked in three different concentrations of colchicine $(5,10,15 \mathrm{mg} / \mathrm{l})$ for 24,48 , and 72 hours, while the control group was soaked in water. A plot of land measuring $10 \times 10$ meters in the University of Calabar Experimental farm was used. Four beds were made and three seeds were sown in per hole using a Randomized Complete Block Design (RCBD) in a 2X3X4 factorial experiment layout with 5 replications. At the end of the field experiment, phenological, yield and yield-related traits were collected and subjected to analysis of variance using Predictive Analytical Software (PASW) version 20. Results obtained showed that there were significant effect of colchicine on phenological traits except on germination. However, there were significant increasing effects on yield and yield-related traits, which was colchicine concentration, exposure time as well as accession-specific. Exposing winged bean seeds to $15 \mathrm{mg} / \mathrm{l}$ of colchicine for 24 and 48 hour duration gave encouraging results and should be considered for further tests and exploitation.
\end{abstract}

KEYWORDS: Ploidy determination, flow cytometry, mutation breeding, colchicine, Psophoscarpus tetragonolobus

\section{INTRODUCTION}

Ploidy of a plant's genome plays an important role in evolution and plant's diversity (Wang et al., 2006; Gaeta et al., 2007). Determination of the ploidy of plants was done traditionally by chromosome counting of stained root tips under microscope (Sakiroglu and Brummer, 2011). This conventional method though good is however rather laborious, time-consuming and only few samples can be handled at a time.Recently, reported is the flow cytometric method, which is a more sensitive, more efficient, reproducible and cost effective with a good capacity to estimate relative nuclear DNA content as well as ploidy level of a large number of species (Ochatt, 2006).

The phenomenon of polyploidization of plant species has significant impact on crop breeding, development and improvement as reported by several authors (Ciftci et al., 2006;Bouriema et al., 2009; Brisibe et al., 2011; Udensi et al., 2012; Udensi et al., 2014). The cause of polyploidization may either be by natural phenomenon or induced mutation using chemicals such as orzyalin, colchicine, and amiprophos methyl. It could also be through irradiations (x-rays, gamma rays, neutrons). In all cases, mutation creates variability and variability is pivotal in breeding programmes with the resultant production of crops that will perform better (Udensi et al., 2012; Udensi et al., 2014).

Presently, the problem of food security in the world, especially in Sub-Saharan African (SSA) countries is climate change, which has adversely affected food productivity through drought, desertification, flooding, temperature increase and epidemics of pests/diseases. Efforts therefore should be geared towards mitigating the problem firstly by exploring crops with inherent capacity to withstand biotic and abioticstressors and secondly, enhancing them through improvement. Exploration and exploitation of under-utilized and extinct-threatened crop plants, especially in Africa that is hunger ravaged and malnutrition scourged has become imperative

One of such crops is winged bean $[P$. tetragonolobus (L) DC], which has been branded, "supermarket" as all its parts are edible. This nutrient

O. U. Udensi, Plant Genetic Resources \& Management Unit, Department of Genetics and Biotechnology, University of Calabar, Nigeria.

E. V. Ikpeme, Plant Genetic Resources \& Management Unit, Department of Genetics and Biotechnology, University of Calabar, Nigeria.

L. I. Emeagi, Plant Genetic Resources \& Management Unit, Department of Genetics and Biotechnology, University of Calabar, Nigeria. 
rich crop makes it a viable option for exploitation as the seeds (cooked/roasted) contain $35 \%$ protein and $17 \%$ oil; flower (salad) contains $10-16 \%$ protein; roots (eaten when boiled) contain $20 \%$ protein. It is rich in tocopherol, vitamins $A$ and $C$ and minerals such as calcium and iron. According to Yang and Tan (2011) it has been reported to be a replacement of fish meal in African Catfish.

Important to mention here that there are no known reports or documentations of mutagenic treatment on winged bean, especially using graded dosages, varying exposure time and colchicine at the disposal of the authors. The two cardinal issues are to evaluate their adaptation(given that it is grown in Nigeria) as well as determine their response to colchicine-induced mutation with the view to improving them.

\section{MATERIALS AND METHOD}

\section{Seed collection and planting}

Twenty accessions of winged bean (Psophocarpus tetragonolobus (L.) DC.) were collected from Genetic Resource Unit of the International Institute of Tropical Agriculture (IITA), Ibadan, Nigeria. TPt-6 was also obtained from the same unit and used as standard (genotype with known ploidy level) for the ploidy analysis. The seeds were sown in experimental pots that were arranged in a completely randomized design (CRD) in the green house of the International Institute of Tropical Agriculture(IITA), Nigeria. Three seeds were sown per pot. Eight weeks after seedling emergence, leaves were harvested and used for the ploidy analysis using flow cytometric protocol.

\section{Flow cytometry analysis}

Approximately $50 \mathrm{~mm}^{2}$ of young fresh and intact leaves of winged bean (grown in the green house) from 21 different accessions were used. Crude isolation of nuclei was done by chopping the leaf in $1 \mathrm{ml}$ of ice cold buffer from DNA kit (cysteine UV Partec GmbH Germany) using a razor blade. The crude suspension was then filtered through a $30 \mu \mathrm{m}$ pore diameter nylon mesh and stained with 4,6- diaminodino-2-phenylindole (DAPI). Fluorescence intensity of isolated nuclei was measured using a partec PAll flow cytometry equipped with an argon ion laser at $488 \mathrm{~nm}$. The flow speed was 30 fluorescence events per second in all cases and fluoresence of at least 5,000 particles (counts) was recorded. This was carried out in the molecular/cytology laboratory of the International Institute of Tropical Agriculture (IITA), Ibadan, Nigeria.

\section{Field experiment}

Out of the 21 accessions collected from IITA germplasm, Seed of two winged bean accessions TPt154 and TPt - 26 were chosen for mutation induction. This choice was premised on already reported varietyspecific sensitivity of some legumes to induced mutagenesis (Udensi et al., 2012) not based on any known agronomic traits. Colchicine was obtained from the Department of Genetics and Biotechnology, University of Calabar, Calabar. Twenty seeds from each accession were soaked in three different concentrations of colchicine, $5,10,15 \mathrm{mg} / \mathrm{L}$, for 24,48 , and 72 hours, respectively while the control group was soaked in water in the cytology laboratory of the Department of Genetic and Biotechnology, University of Calabar, Calabar.

\section{Experimental plot and cultural practices}

A plot of land measuring 10X10 meters was manually cleared in the University of Calabar Experimental farm. Four beds were made and three seeds were sown in per hole using a Randomized Complete Block Design (RCBD) in a 2X3X4 factorial experiment layout with 5 replications. Two weeks after seedling emergence, seedlings were thinned down to 2 per stand. Cultural practices including staking and weeding were done as the need arose.

\section{Data collection and analysis}

At the end of the experiment, data on percentage germination, days to seedling emergence, percentage seedling emergence, days to $50 \%$ percent flowering, days to $50 \%$ percent maturity, vein length, leaf area, internode length, number of branches, number of flowers per plant, number of pod per plants, number of seed per pod, pod length, 100 seed weight and seed yield(weight of seeds per concentration) were collected. Data collected were subjected to analysis of variance using PASW software version 20.

\section{RESULTS}

\section{Ploidy analysis}

In order to assess the ploidy level of the accessions, we compared the fluorescence densities of the 20 samples to the already known diploid standard TPt 6 . The result revealed that all the winged bean accessions screened for ploidy level had diploid chromosome. The coefficient of variation ranged from $1.34 \%-7.96 \%$ with mean that ranged from 48.01-56.04 (Table 1). 
Table 1: Winged bean accessions used, Coefficient of variation, mean and the ploidy levels

\begin{tabular}{|c|c|c|c|c|c|}
\hline $\mathrm{S} / \mathrm{N}$ & $\begin{array}{l}\text { Winged bean } \\
\text { Accessions }\end{array}$ & $\begin{array}{l}\text { Location acquired from } \\
\text { by IITA }\end{array}$ & $\begin{array}{ll}\text { Coefficient } & \text { of } \\
\text { variation }(\mathrm{CV})[\%]\end{array}$ & Mean & Ploidy level \\
\hline 1 & TPt-6 (standard) & India & 4.69 & 48.01 & Diploid \\
\hline 2 & TPt-154 & NA & 2.51 & 49.73 & Diploid \\
\hline 3 & TPt-51 & NA & 3.31 & 52.89 & Diploid \\
\hline 4 & TPt-53 & NA & 7.96 & 53.42 & Diploid \\
\hline 5 & TPt-17 & Thailand & 6.18 & 52.57 & Diploid \\
\hline 6 & TPt-26 & NA & 5.14 & 53.47 & Diploid \\
\hline 7 & TPt-43 & NA & 3.24 & 53.94 & Diploid \\
\hline 8 & TPt-15 & Thailand & 2.25 & 55.52 & Diploid \\
\hline 9 & TPt-33 & NA & 4.23 & 53.15 & Diploid \\
\hline 10 & TPt-16 & Thailand & 1.34 & 56.04 & Diploid \\
\hline 11 & TPt-19 & Thailand & 3.31 & 52.93 & Diploid \\
\hline 12 & TPt-2 & India & 7.06 & 53.36 & Diploid \\
\hline 13 & TPt-1A & NA & 5.81 & 55.91 & Diploid \\
\hline 14 & TPt-12 & NA & 6.67 & 48.70 & Diploid \\
\hline 15 & TPt-11 & NA & 6.08 & 53.42 & Diploid \\
\hline 16 & TPt-14 & Thailand & 2.32 & 53.78 & Diploid \\
\hline 17 & TPt-10 & NA & 4.22 & 53.34 & Diploid \\
\hline 18 & TPt-4 & India & 7.75 & 48.36 & Diploid \\
\hline 19 & TPt-9 & India & 7.72 & 48.72 & Diploid \\
\hline 20 & TPt-5 & India & 6.14 & 53.47 & Diploid \\
\hline 21 & TPt-2A & NA & 6.19 & 52.52 & Diploid \\
\hline
\end{tabular}

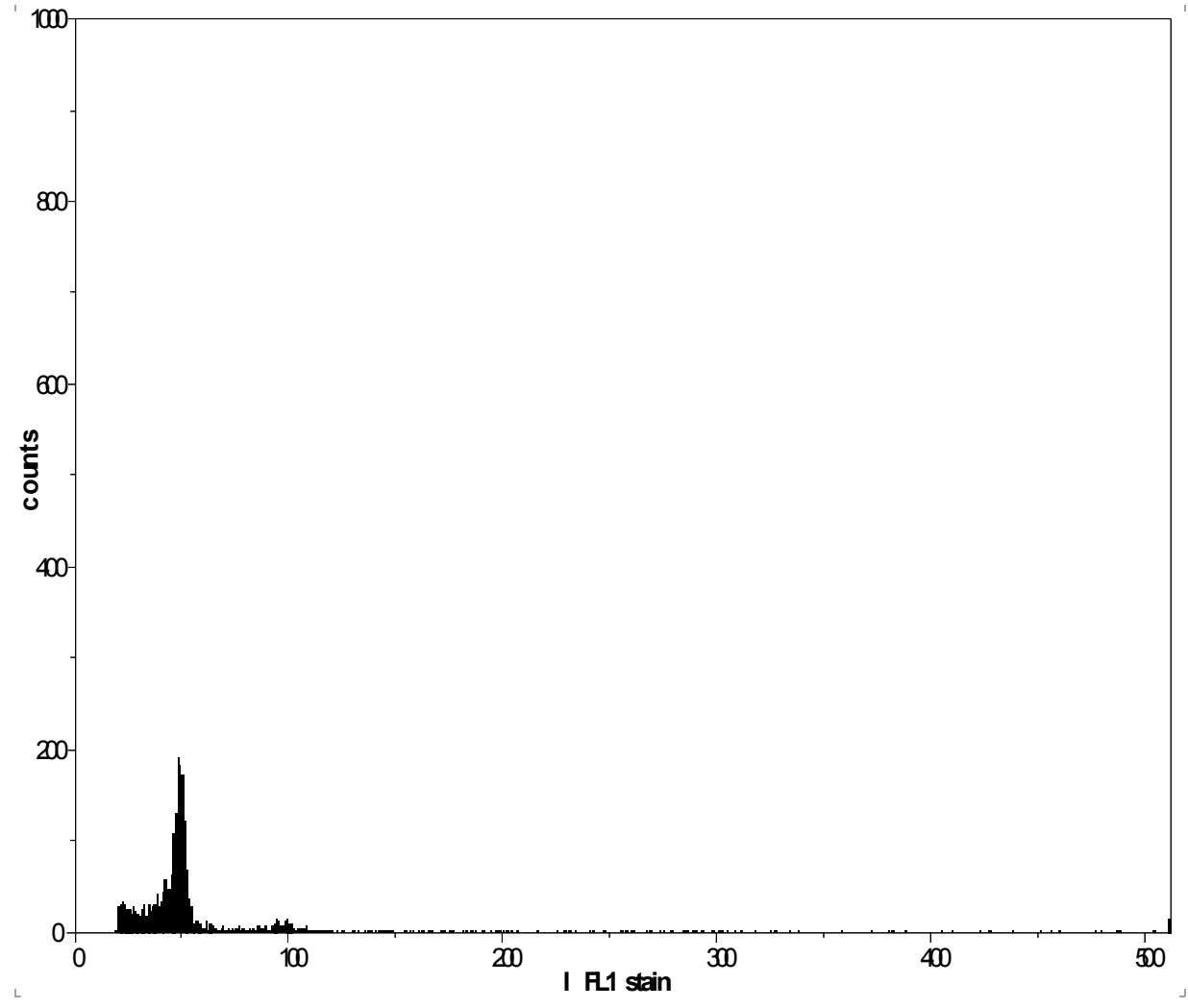

(a) 

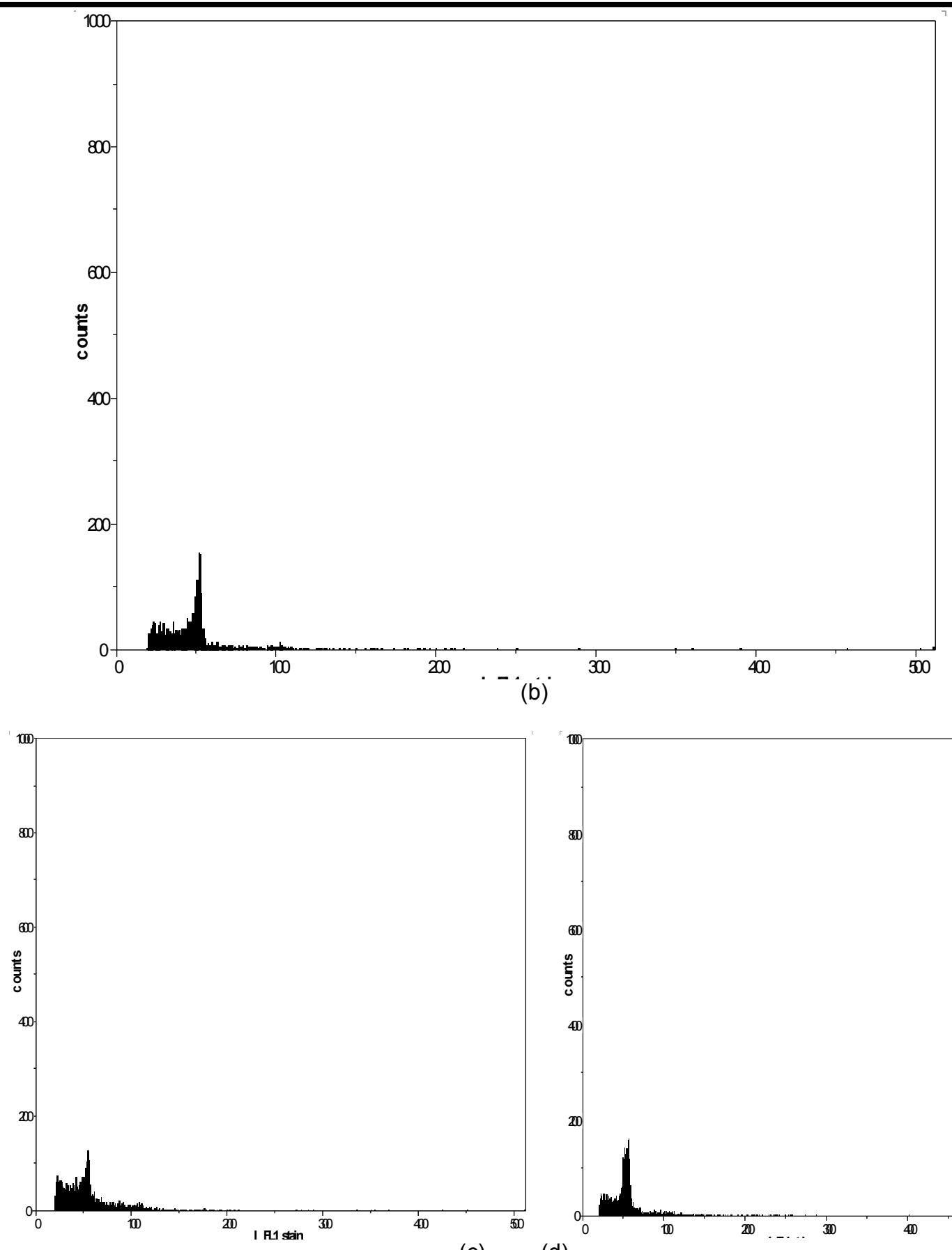

(c)

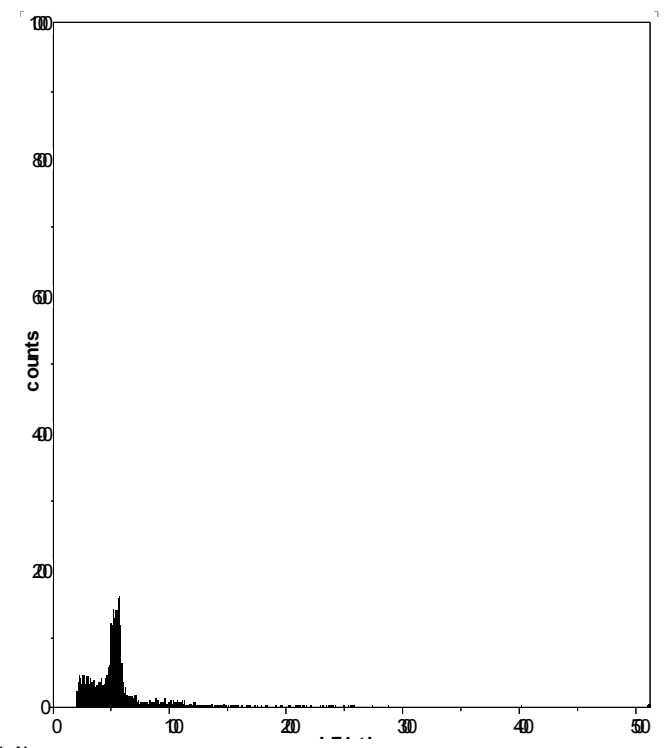

(d)

Fig 1: Flow ctyometry analysis of $P$. tetragonolobus accessions from IITA, Ibadan, Nigeria [(a)TPt-6 as standard; (b)TPt-154; (c) TPt-51; (d) TPt-53] 


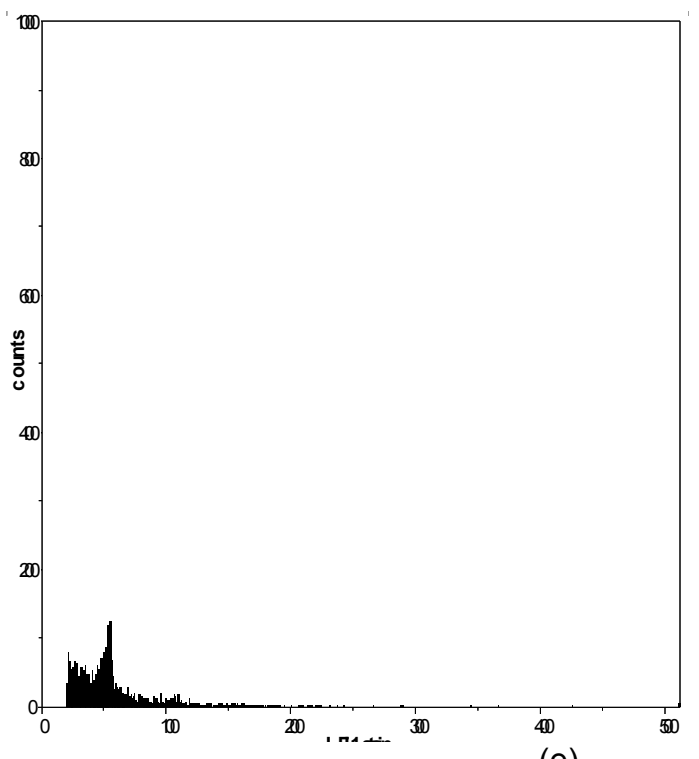

(e)

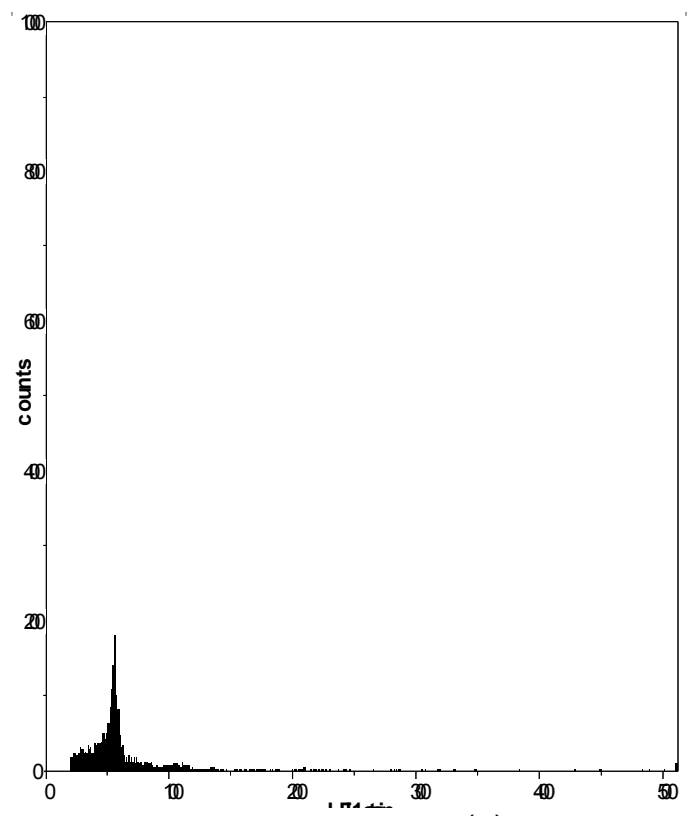

(g)
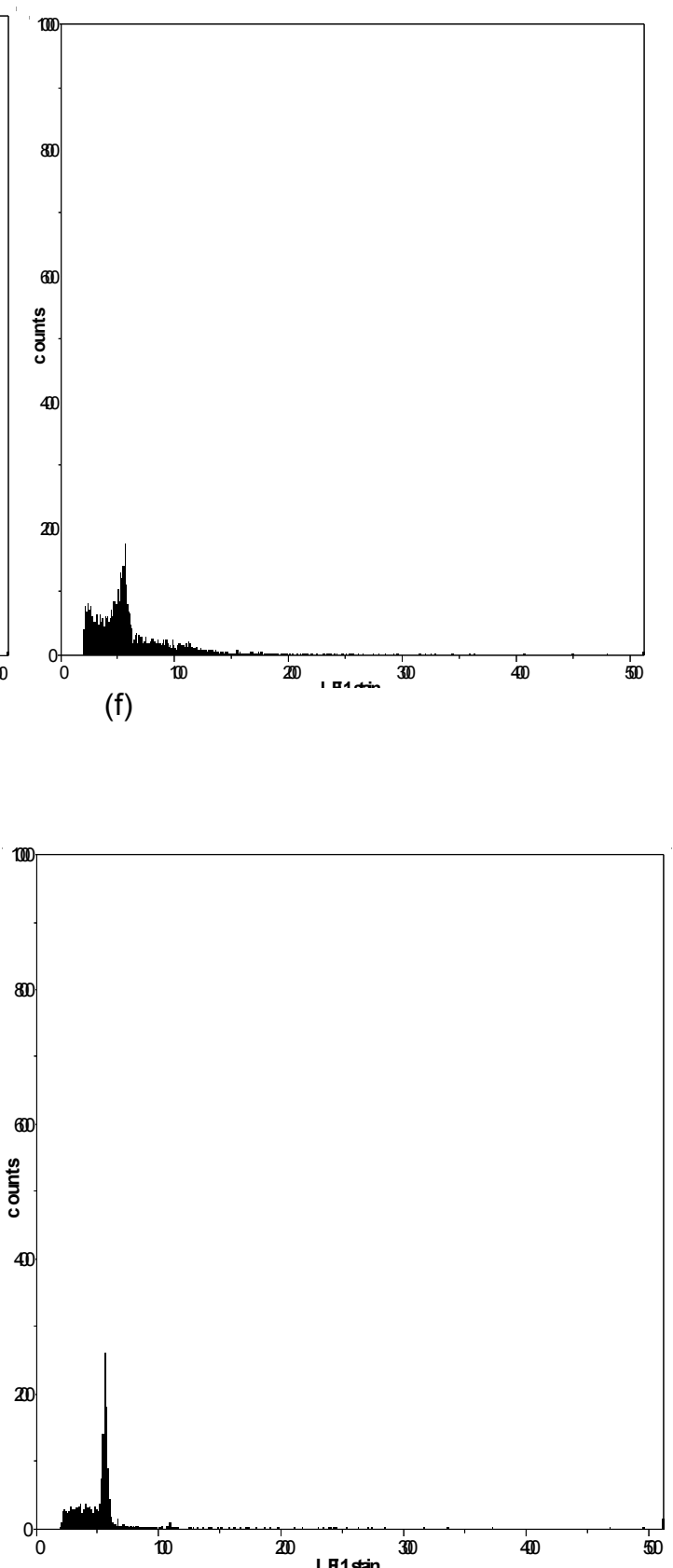

(h)

Fig 2: Flow ctyometry analysis of $P$. tetragonolobus accessions from IITA, Ibadan, Nigeria [(e)TPt-17; (f)TPt-26; (g) TPt-43; (h) TPt-15] 

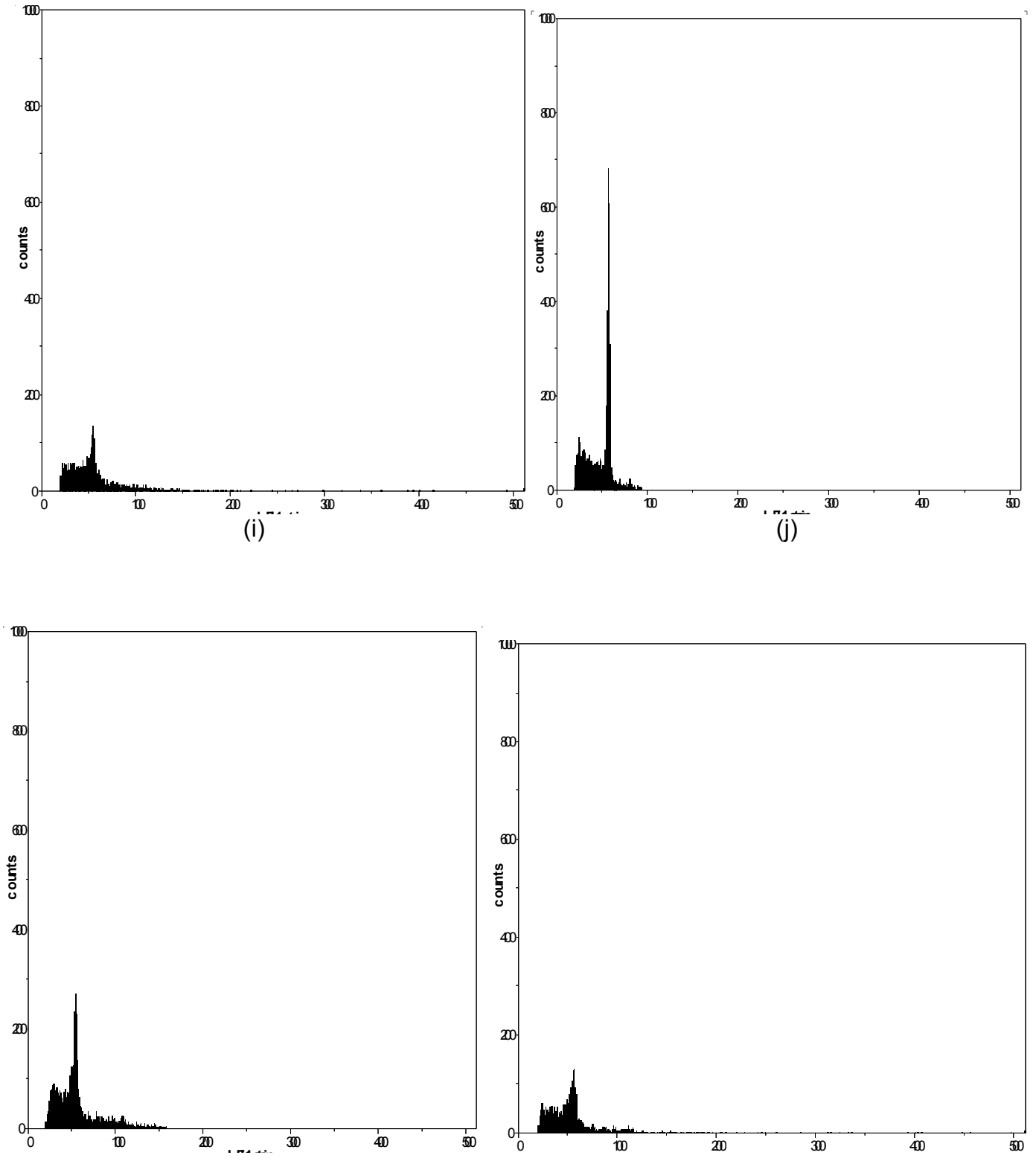

(k)

(I)

Fig 3: Flow ctyometry analysis of $P$. tetragonolobus accessions from IITA, Ibadan, Nigeria [(i)TPt-33 (j)TPt-16; (k) TPt19; (I) TPt-2] 

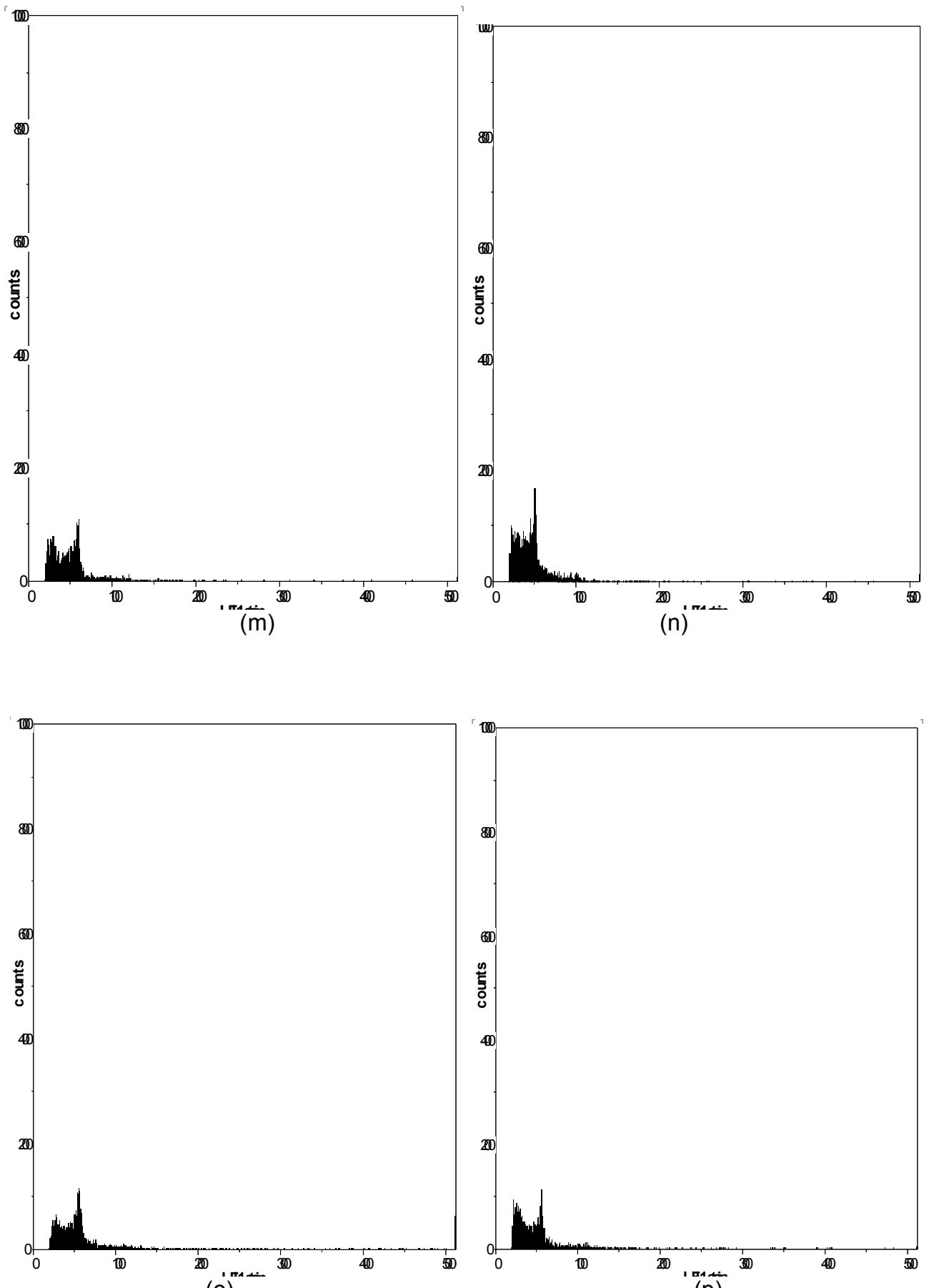

(o)

(p)

Fig 4: Flow ctyometry analysis of $P$. tetragonolobus accessions from IITA, Ibadan, Nigeria [(m)TPt-1A; (n)TPt-12; (o) TPt-11; (p) TPt-14] 


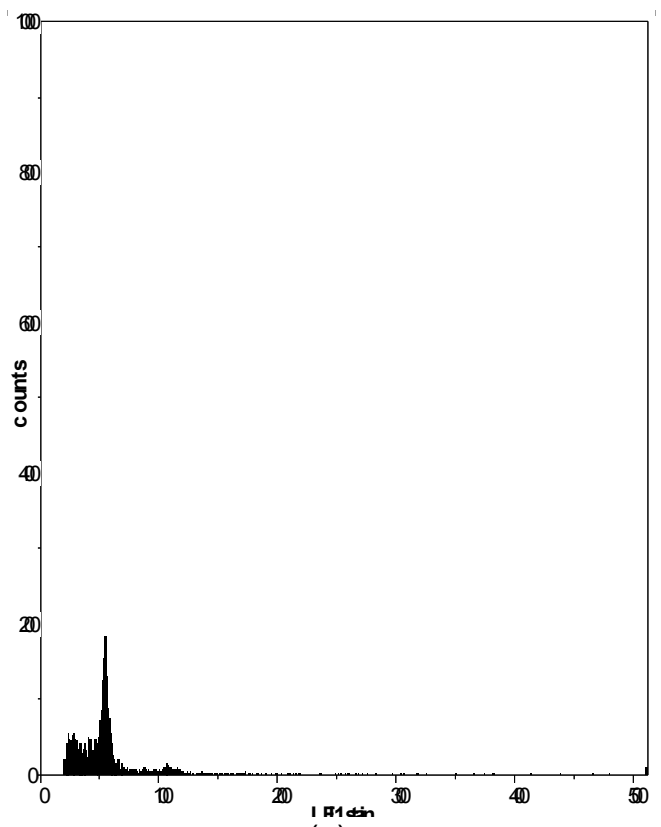

(q)

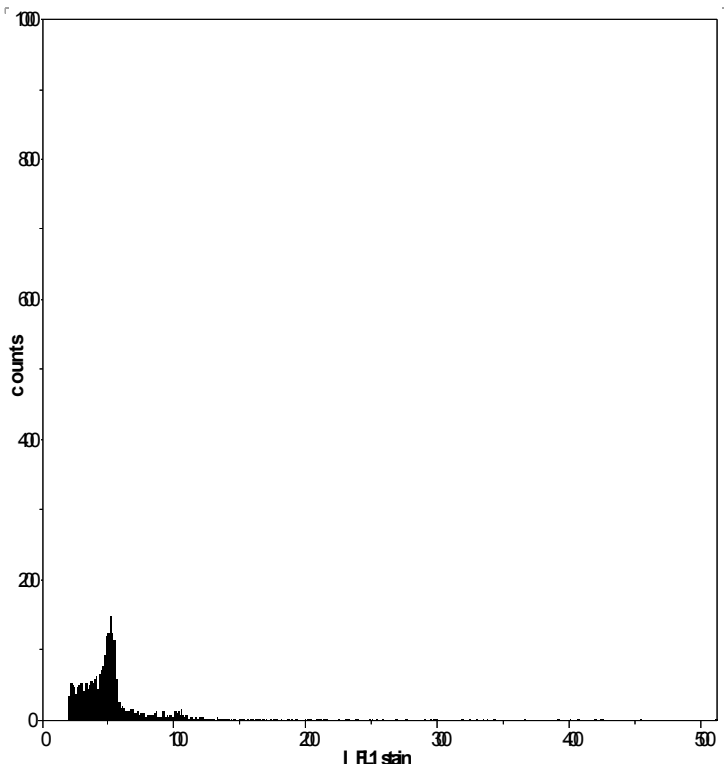

(s)

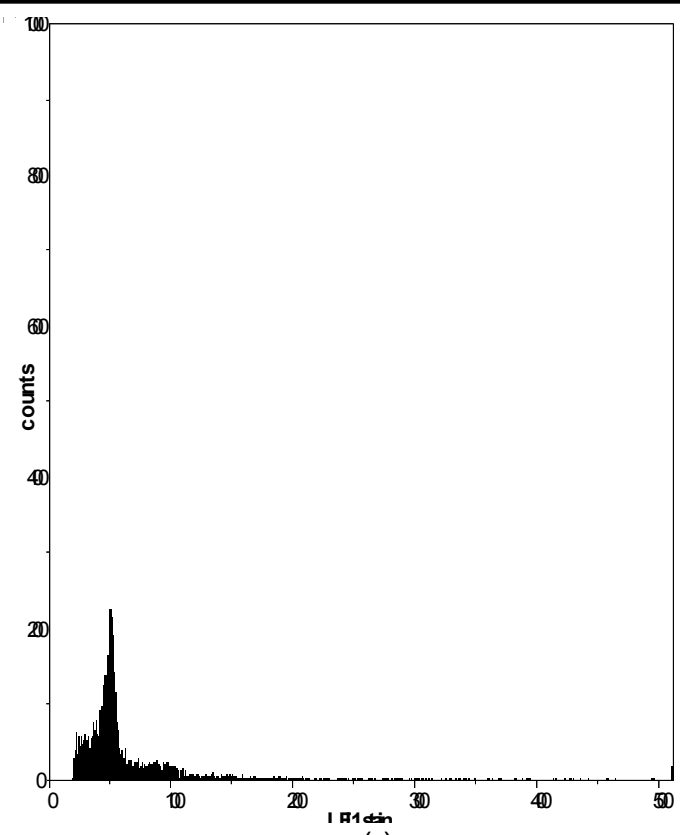

$(r)$

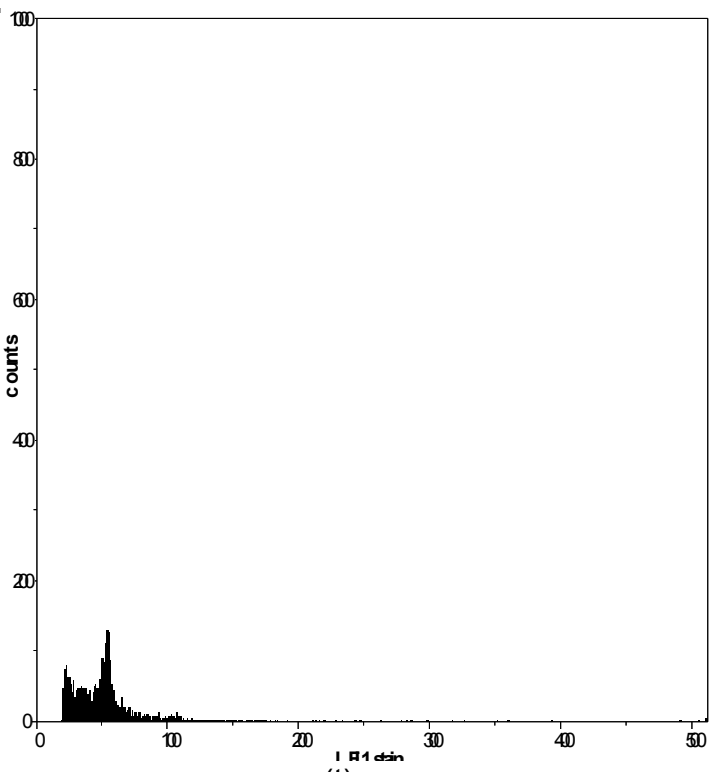

$(\mathrm{t})$

Fig 5: Flow ctyometry analysis of $P$. tetragonolobus accessions from IITA, Ibadan, Nigeria [(q)TPt-10; (r)TPt-4; (s) TPt-9; (t) TPt-5] 


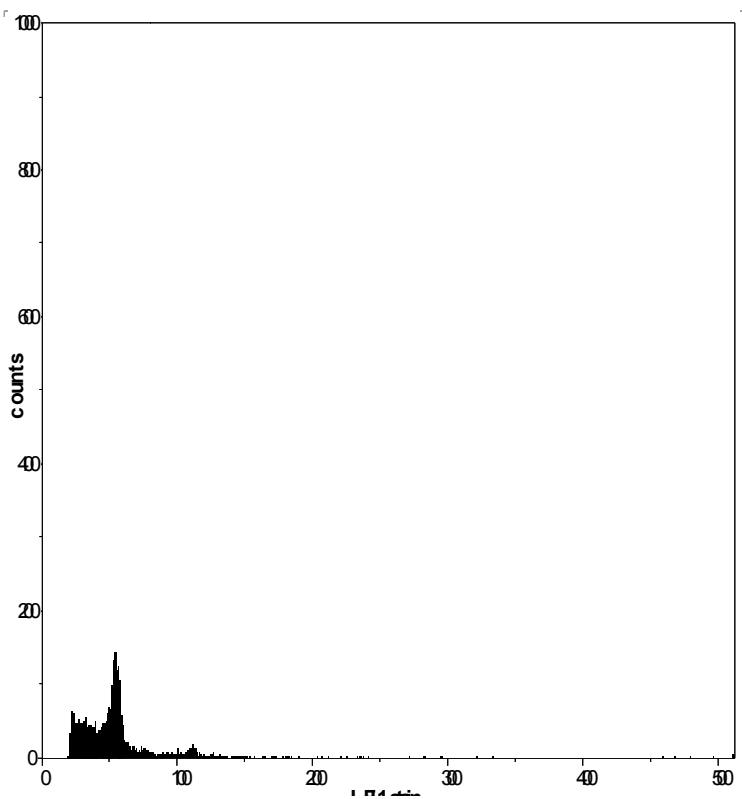

Fig 6: Flow ctyometry analysis of $P$. tetragonolobus accession from IITA, Ibadan, Nigeria [(u)TPt-2A

\section{Phenological traits in winged bean}

For the phenological traits assessed (days to seedling emergence, percentage seedling emergence, days to $50 \%$ flowering, and days to $50 \%$ pod maturity), we represented results on a single chart because it was observed that the effects of colchicine on winged bean were concentration and exposure time dependent rather than accession-based. The days it took the seedlings to emerge increased with colchicine concentration and exposure time. Conversely, percentage seedling emergence decreased with increase in concentration and exposure time. However, when the two winged bean accessions were compared, result revealed that germination percentage of TPt26 was significantly reduced $(50 \%)(\mathrm{P}<0.05)$ while TPt154 was $66.7 \%$. Additionally, while days to $50 \%$ flowering was not significantly affected by colchicine concentration and exposure time, days to $50 \%$ pod maturity was slightly increased (Figures 1-4).

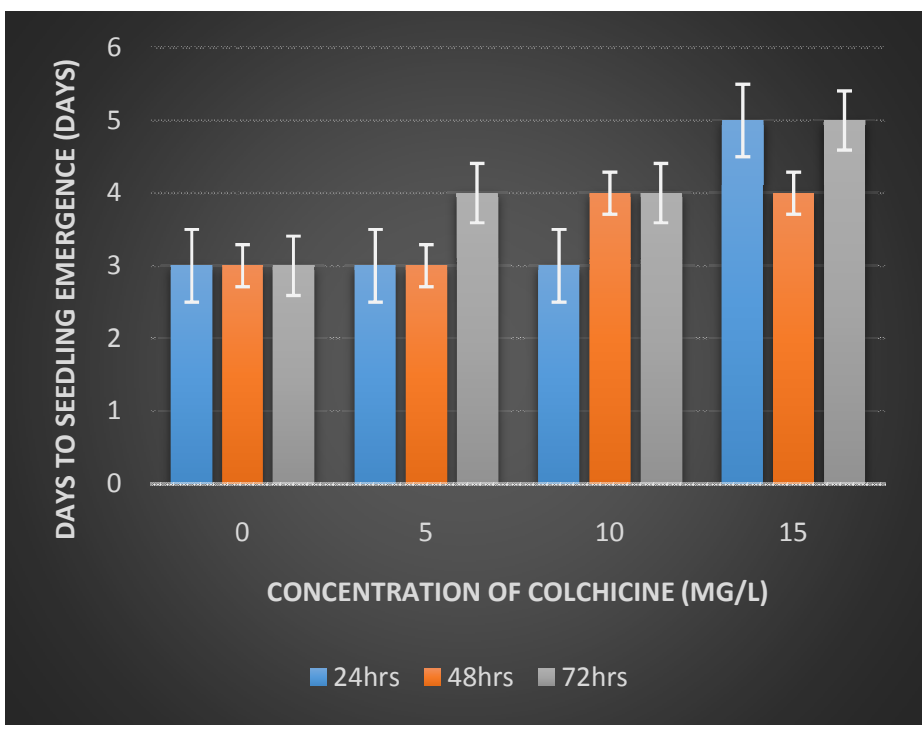

Figure 7: Effect of colchicine concentration and exposure time on days to seedling emergence (days) in $P$. tetragonolobus 

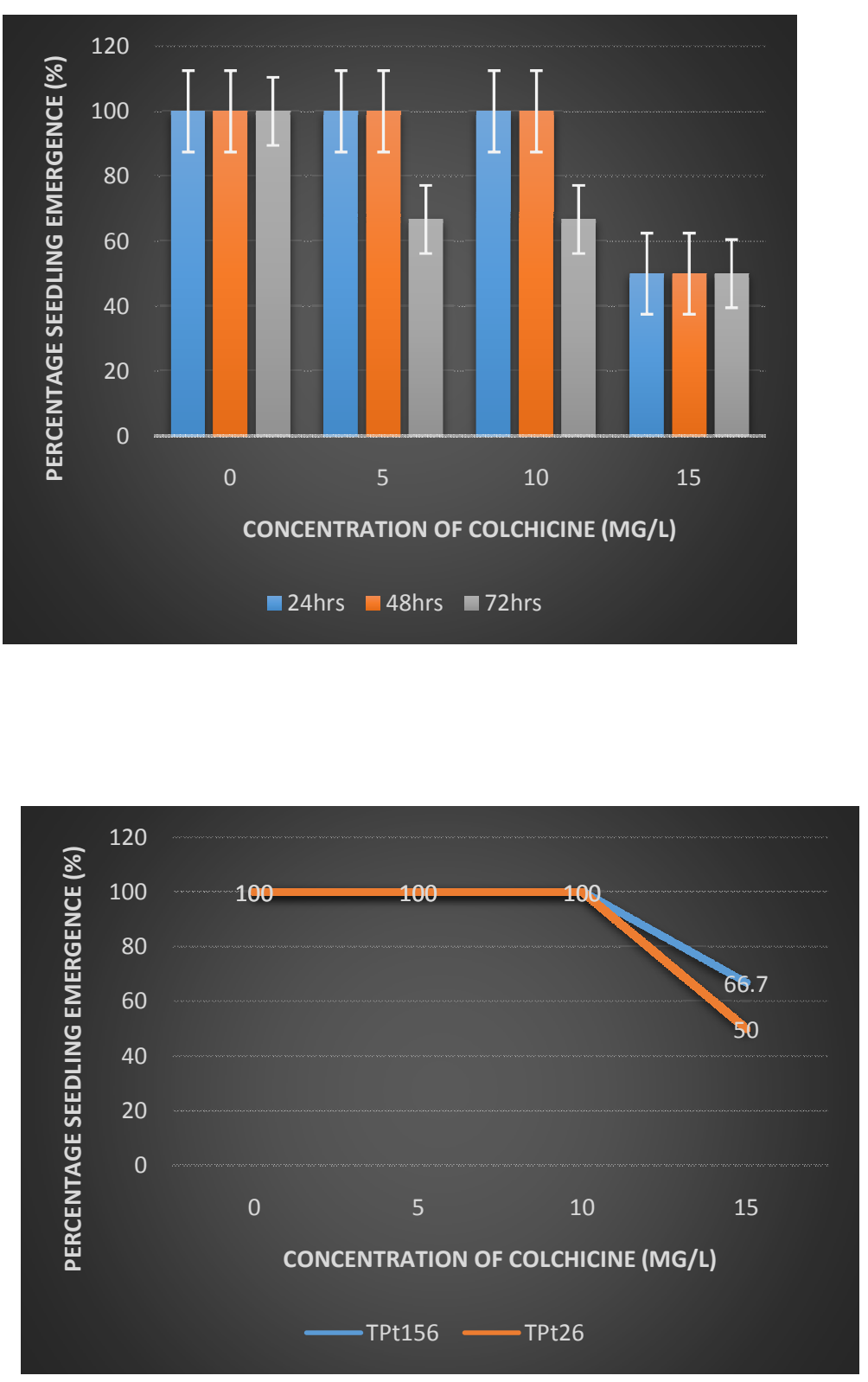

Figure 8a \& b: Effect of colchicine concentration and exposure timeon percentage seedling emergence in $P$. tetragonolobus 


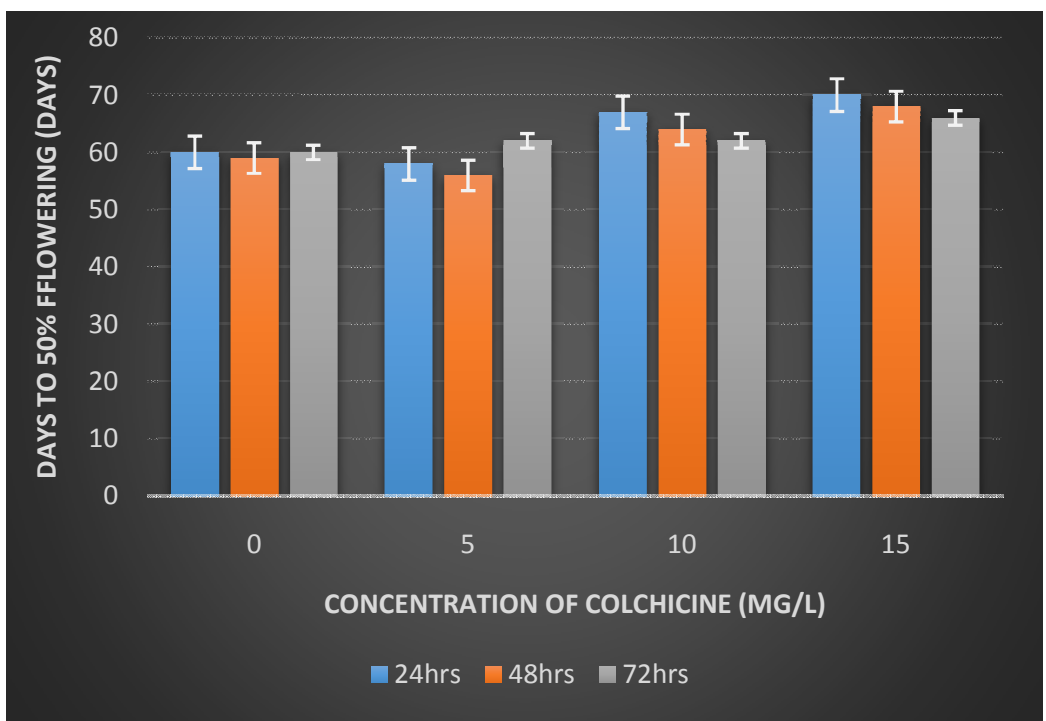

Figure 9: Effect of colchicine concentration and exposure timeon days to $50 \%$ flowering (days) in $P$. tetragonolobus

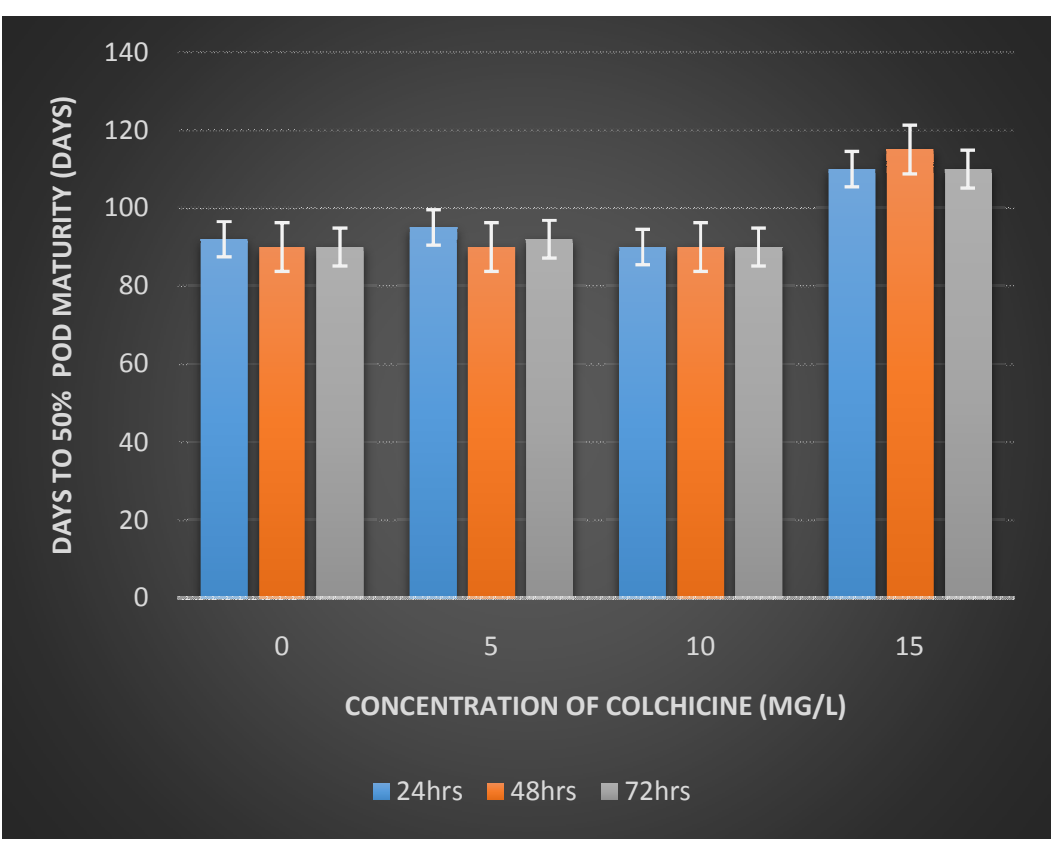

Figure 10: Effect of colchicine concentration and exposure time on days to $50 \%$ pod maturity (days) in $P$. tetragonolobus 

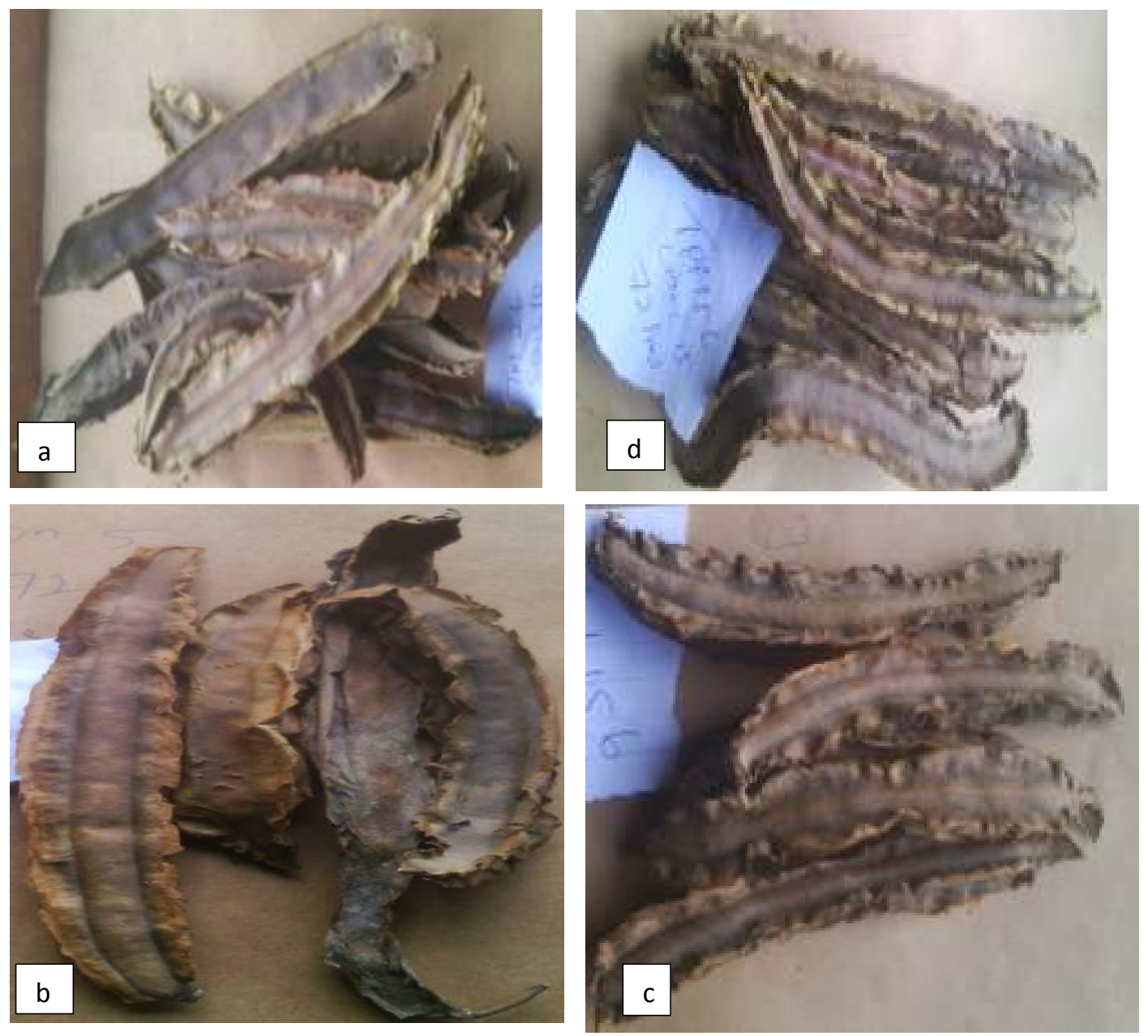

Plate 1a-d: Effect of colchicine on the pods of $P$. tetragonolobus $(\mathrm{a}=$ control; $\mathrm{b}=5 \mathrm{mg} / \mathrm{l}$ for $24 \mathrm{hrs} ; \mathrm{c}=10 \mathrm{mg} / \mathrm{l}$ for $24 \mathrm{hrs}$; $\mathrm{d}=15 \mathrm{mg} / \mathrm{l}$ for $72 \mathrm{hrs}$ )

\section{Effect of colchicine treatment on yield related traits of $P$. tetragonolobus \\ Colchicine \\ treatment \\ significantly}

affected $(P<0.05)$ yield related traits, which was both mutagen concentration and exposure time dependent. TPt154 seeds soaked in 10 and $15 \mathrm{mg} / \mathrm{l}$ of colchicine for 48 hours exposure time produced plants with the longest vein length. Additionally, when the seeds were soaked in $15 \mathrm{mg} / \mathrm{l}$ of colchicine for 24,48 and 72 hours, respectively, plants raised had the highest number of leaves. Similarly, plants raised from TPt26 seeds soaked in $15 \mathrm{mg} / \mathrm{l}$ of colchicine for 24 hours did not differ significantly $(P>0.05)$ with those plants from TPt154 for number of leaves. The same trend was followed for leaf area, internode length as well as number of branches per plant (Table 2).

\section{Effect of colchicine treatment on yield traits of $P$. tetragonolobus}

Results obtained showed that the effect of colchicine induction on yield traits increased significantly $(P<0.05)$ as the colchicine concentration and exposure time increased, though this trend was not consistent in all. Seeds treated with $15 \mathrm{mg} / \mathrm{l}$ of colchicine for 24 and 48 hours, respectively performed better comparatively, the winged bean accession used notwithstanding for number of flowers produced, pod length, number of seeds per pod and seed yield. However, comparing plants raised from seeds of TPt26 and TPt154 soaked in $15 \mathrm{mg} / \mathrm{l}$ for 24 and 48 hours, plants of TPt154 performed better in all the yield traits evaluated, especially when the seeds were exposed in colchicine for 48 hours (Table 3). 
Table 2: Effect of colchicine treatment on yield -related traits in $P$. tetragonolobus (L.) DC

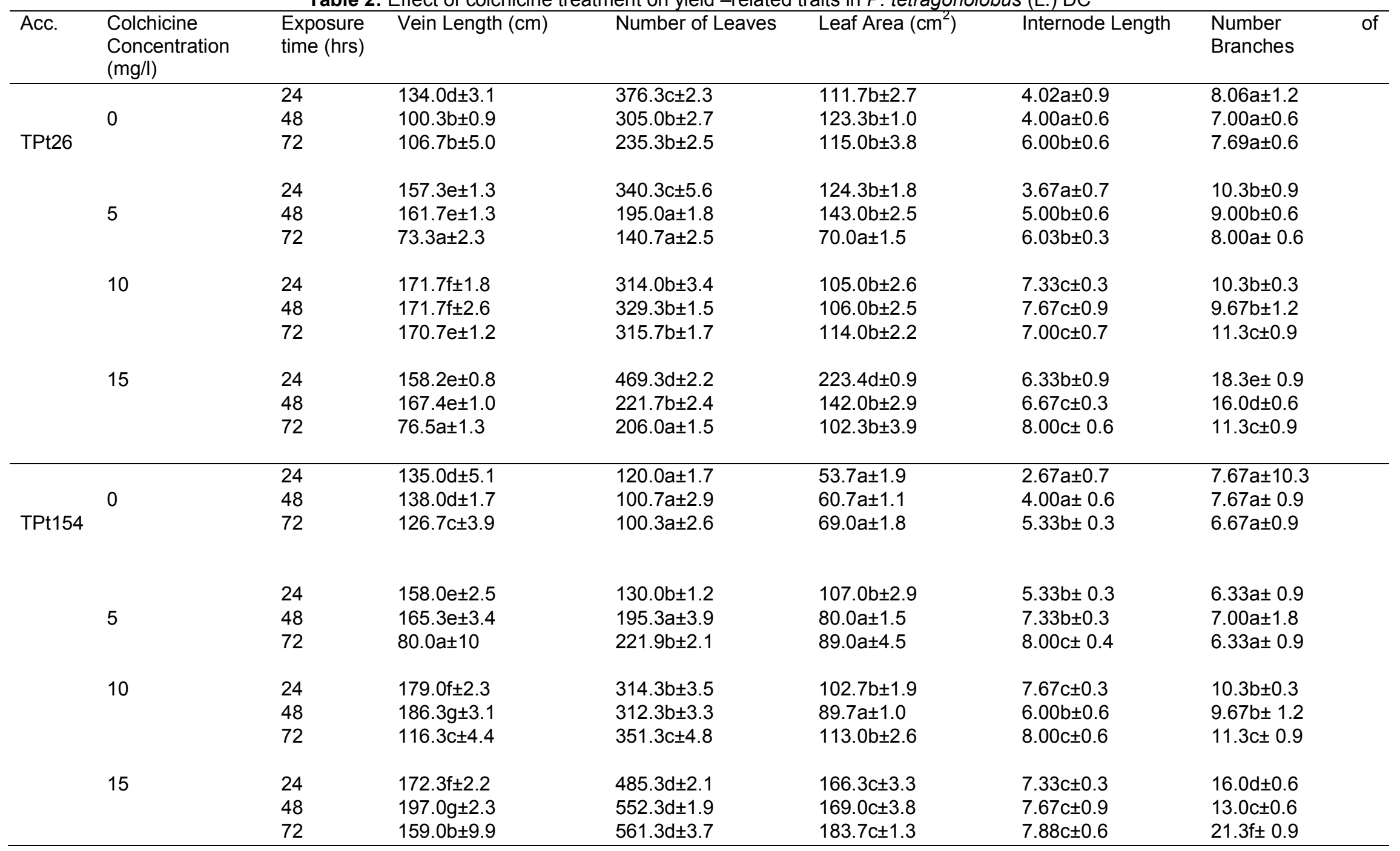




\begin{tabular}{|c|c|c|c|c|c|c|c|}
\hline Acc. & $\begin{array}{l}\text { Colchicine } \\
\text { Concentration } \\
\text { (mg/l) }\end{array}$ & $\begin{array}{l}\text { Exposure } \\
\text { time (hrs) }\end{array}$ & Number of flowers & Pod length $(\mathrm{cm})$ & Number of pods & $\begin{array}{l}\text { Number of seeds } \\
\text { per pod }\end{array}$ & Seed yield $(\mathrm{g})$ \\
\hline & 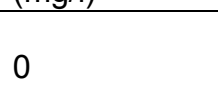 & $\begin{array}{l}24 \\
48\end{array}$ & $\begin{array}{l}10.3^{\mathrm{a}} \pm 0.9 \\
12.3^{\mathrm{a}} \pm 2.3\end{array}$ & $\begin{array}{l}7.3^{\mathrm{a}} \pm 0.3 \\
8.3^{\mathrm{a}} \pm 0.3\end{array}$ & $\begin{array}{l}6.2^{\mathrm{a}} \pm 0.4 \\
7.1^{\mathrm{a}} \pm 0.3\end{array}$ & $\begin{array}{l}11.3^{\mathrm{b}} \pm 0.3 \\
11.7^{\mathrm{b}} \pm 0.9\end{array}$ & $\begin{array}{l}67.98^{\mathrm{c}} \pm 0.8 \\
81.69^{\mathrm{d}} \pm 0.7\end{array}$ \\
\hline TPt26 & & 72 & $13.0^{\mathrm{a}} \pm 0.6$ & $6.7^{\mathrm{a}} \pm 0.3$ & $6.5^{\mathrm{a}} \pm 0.3$ & $11.7^{\mathrm{b}} \pm 1.2$ & $85.54^{d} \pm 0.3$ \\
\hline & 5 & $\begin{array}{l}24 \\
48 \\
72\end{array}$ & $\begin{array}{l}23.3^{\mathrm{d}} \pm 1.8 \\
19.0^{\mathrm{c}} \pm 0.6 \\
15.0^{\mathrm{b}} \pm 0.9\end{array}$ & $\begin{array}{l}10.3^{\mathrm{b}} \pm 0.9 \\
8.0^{\mathrm{a}} \pm 0.6 \\
10.7^{\mathrm{b}} \pm 1.2\end{array}$ & $\begin{array}{l}10.0^{\mathrm{b}} \pm 0.2 \\
7.9^{\mathrm{a}} \pm 0.4 \\
10.3^{\mathrm{b}} \pm 0.2\end{array}$ & $\begin{array}{l}13.0^{\mathrm{c}} \pm 1.2 \\
11.7^{\mathrm{b}} \pm 0.9 \\
11.7^{\mathrm{b}} \pm \mathrm{c} 0.9\end{array}$ & $\begin{array}{l}199.29^{i} \pm 0.3 \\
147.85^{\mathrm{h}} \pm 0.8 \\
120.55^{\dagger} \pm 1.4\end{array}$ \\
\hline & 10 & $\begin{array}{l}24 \\
48 \\
72\end{array}$ & $\begin{array}{l}18.3^{\mathrm{b}} \pm 1.8 \\
18.7^{\mathrm{D}} \pm 1.2 \\
16.7^{\mathrm{b}} \pm 1.5\end{array}$ & $\begin{array}{l}12.3^{\mathrm{c}} \pm 0.6 \\
11.3^{\mathrm{c}} \pm 0.9 \\
10.3 \mathrm{~b} \pm 0.7\end{array}$ & $\begin{array}{r}12.9^{\mathrm{c}} \pm 0.3 \\
13.4^{\mathrm{c}} \pm 0.5 \\
9.7^{\mathrm{b}} \pm 0.6\end{array}$ & $\begin{array}{l}12.3^{\mathrm{b}} \pm 0.7 \\
12.0^{\mathrm{D}} \pm 0.4 \\
11.0^{\mathrm{b}} \pm 0.6\end{array}$ & $\begin{array}{l}135.63^{\mathrm{g}} \pm 1.1 \\
154.00^{\mathrm{n}} \pm 0.5 \\
110.00^{\mathrm{e}} \pm 0.8\end{array}$ \\
\hline & 15 & $\begin{array}{l}24 \\
48 \\
72\end{array}$ & $\begin{array}{l}27.7^{\mathrm{d}} \pm 1.5 \\
27.3^{\mathrm{a}} \pm 1.8 \\
19.0^{\mathrm{c}} \pm 1.2\end{array}$ & $\begin{array}{l}11.7^{\mathrm{c}} \pm 1.2 \\
8.0^{\mathrm{a}} \pm 0.6 \\
11.0^{\mathrm{b}} \pm 1.2\end{array}$ & $\begin{array}{l}8.2 \mathrm{a} \pm 0.4 \\
11.4^{\mathrm{c}} \pm 1.2 \\
10.5^{\mathrm{b}} \pm 1.4\end{array}$ & $\begin{array}{l}12.7^{\mathrm{c}} \pm 0.9 \\
14.7^{\mathrm{c}} \pm 0.3 \\
11.0^{\mathrm{b}} \pm 0.7\end{array}$ & $\begin{array}{l}266.07^{\mathrm{k}} \pm 1.7 \\
239.56^{\prime} \pm 2.2 \\
135.63^{\mathrm{g}} \pm 1.3\end{array}$ \\
\hline TPt154 & 0 & $\begin{array}{l}24 \\
48 \\
72\end{array}$ & $\begin{array}{l}11.7^{\mathrm{a}} \pm 1.2 \\
13.0^{\mathrm{a}} \pm 1.7 \\
15.3^{\mathrm{b}} \pm 2.9\end{array}$ & $\begin{array}{l}8.0^{\mathrm{a}} \pm 0.6 \\
7.0^{\mathrm{a}} \pm 0.6 \\
7.7^{\mathrm{a}} \pm 0.9\end{array}$ & $\begin{array}{l}6.3^{\mathrm{a}} \pm 0.9 \\
7.3^{\mathrm{a}} \pm 0.9 \\
7.7^{\mathrm{a}} \pm 0.3\end{array}$ & $\begin{array}{l}6.7^{\mathrm{a}} \pm 0.3 \\
8.0^{\mathrm{a}} \pm 0.6 \\
6.3^{\mathrm{a}} \pm 0-.3\end{array}$ & $\begin{array}{l}42.22^{\mathrm{a}} \pm 0.3 \\
58.64^{\mathrm{b}} \pm 0.7 \\
48.55^{\mathrm{a}} \pm 0.6\end{array}$ \\
\hline & 5 & $\begin{array}{l}24 \\
48 \\
72\end{array}$ & $\begin{array}{l}26.0^{\mathrm{d}} \pm 2.1 \\
16.7^{\mathrm{b}} \pm 1.7 \\
16.0^{\mathrm{b}} \pm 1.5\end{array}$ & $\begin{array}{l}9.3^{\mathrm{b}} \pm 0.3 \\
8.3^{\mathrm{a}} \pm 0.9 \\
7.0^{\mathrm{a}} \pm 0.6\end{array}$ & $\begin{array}{l}8.3^{\mathrm{b}} \pm 0.9 \\
16.0^{\mathrm{e}} \pm 0.6 \\
11.3^{\mathrm{c}} \pm 0.7\end{array}$ & $\begin{array}{l}10.7^{\mathrm{b}} \pm 0.3 \\
10.7^{\mathrm{b}} \pm 0.5 \\
7.3^{\mathrm{a}} \pm 0.3\end{array}$ & $\begin{array}{l}170.72^{\mathrm{h}} \pm 1.2 \\
88.88^{\mathrm{d}} \pm 1.0 \\
83.04^{\mathrm{d}} \pm 0.9\end{array}$ \\
\hline & 10 & $\begin{array}{l}24 \\
48 \\
72\end{array}$ & $\begin{array}{l}17.7^{\mathrm{b}} \pm 1.2 \\
19.0^{\mathrm{c}} \pm 0.9 \\
15.7^{\mathrm{b}} \pm 1.2\end{array}$ & $\begin{array}{l}12.0^{\mathrm{c}} \pm 0.6 \\
10.0^{0} \pm 0.6 \\
11.0^{\mathrm{b}} \pm 1.5\end{array}$ & $\begin{array}{l}12.3 c \pm 0.9 \\
13.7^{\mathrm{a}} \pm 1.2 \\
12.3^{\mathrm{c}} \pm 1.5\end{array}$ & $\begin{array}{l}13.3^{c} \pm 1.5 \\
12.7^{c} \pm 0.6 \\
13.0^{c} \pm 0.6\end{array}$ & $\begin{array}{l}164.35^{\mathrm{h}} \pm 1.7 \\
164.04^{\mathrm{n}} \pm 1.9 \\
160.29^{\mathrm{h}} \pm 2.3\end{array}$ \\
\hline & 15 & $\begin{array}{l}24 \\
48 \\
72\end{array}$ & $\begin{array}{l}29.3^{\mathrm{d}} \pm 1.8 \\
36.7^{\mathrm{e}} \pm 2.8 \\
17.3^{\mathrm{b}} \pm 1.2\end{array}$ & $\begin{array}{l}8.0^{\mathrm{a}} \pm 0.6 \\
10.7^{\mathrm{b}} \pm 1.2 \\
11.3^{\mathrm{c}} \pm 0.9\end{array}$ & $\begin{array}{l}24.0^{\dagger} \pm 1.6 \\
30.3^{9} \pm 1.9 \\
13.0^{c} \pm 1.6\end{array}$ & $\begin{array}{l}12.7^{\mathrm{c}} \pm 0.4 \\
12.7^{\mathrm{c}} \pm 0.3 \\
14.3^{\mathrm{c}} \pm 0.7\end{array}$ & $\begin{array}{l}304.08^{i} \pm 2.1 \\
384.28^{m} \pm 1.3 \\
186.29^{\prime} \pm 1.6\end{array}$ \\
\hline
\end{tabular}




\section{DISCUSSION}

Obviously, ploidy level determination in crop species is a critical step in evolution, diversity analysis (Wang et al., 2006; Gaeta et al., 2009), plant breeding as well as taxonomy. More importantly, is the application and adoption of flow cytomery in the determination, which guarantees speed, high sensitivity, less tediousness, and is more convenient thus enabling the handling of many samples at a time when compared with the conventional practice of chromosome counting (Udensi and Ntui, 2013a). We report that the winged bean accessions available in the germplasm collection in International Institute for Tropical Agriculture (IITA), Nigeria had diploid number of chromosomes, which confirms the earlier report using squashing and staining method of $2 n=2 x=18$ (Anon, 1981). However, our thinking was that the process of evolution and differentiation may have caused chromosome alteration of these accessions, which may have contributed to polyploidization.

Regrettably, very little research interest has been given to the breeding, improvement and conservation of winged bean even as it is endangered and tilting towards extinction. Crops' response or sensitivity to any mutagenic treatment is not just mutagen, concentration and exposure time dependent but also species-specific (Udensi et al., 2012; Udensi and Ntui, 2013a/b; Udensi et al., 2014). This was the basis for comparing TPt26 and TPt154.Udensi and Ntui, (2013a/b), Udensi et al. (2012) had used similar treatment regimens.

From our present result, the days it took the seeds of the two accessions to emerge was increased significantly $(P<0.05)$. This delay had been blamed on physiological perturbations affecting some biochemical pathways probably enzyme activity, hormonal imbalance, inhibition of mitotic process (Stoeva and Bineva, 2001; Khan and Al-Qurainy, 2009). Similar effects were reported by Uma and Salimath (2001) and Mensah et al (2005) in cowpea, Toker and Cagirgan (2004) in chick pea, Kumar et al. (2003) in Phaseolus lunatus, Pons et al. (2001) in rice, Udensi et al. (2012ac) in cowpea and pigeon pea, respectively though using different mutagens with different concentration and exposure time. According to Udensi and Ntui (2013a), this condition was attributed to the fact the seeds soaked in higher colchicine concentrations in increasing exposure time may possibly have to readjust physiologically in response to the treatment. The aforementioned reviews and our present result might suggest that legumes respond similarly when their seeds are exposed to mutagens.

Expectedly, the longer the vein, the more the number of leaves that will be produced by the plant, the accession notwithstanding. Number of branches also increased in direct proportion to the length of the vein. There is a significant positive correlation between leaf number and photosynthetic rate as well as between leaf area and photosynthesis. These relationship is such that the higher the leaf number, broader the leaf area, the more photosynthetic rate as the interaction between the chlorophyll and the solar catalysis will increase (Udensi and Ikpeme, 2012). It should also be made clear that sometimes this relationship though ideal might undergo some external and internal perturbations, which may not affect yield drastically given that yield is a multi-factored influenced trait.

In the present study, colchicine concentration and exposure time did not significantly affect the days to flowering. However, its production impacted positively on the number of winged bean pods produced. This also led to the increase in the number of seeds produced by each pod with the culminated output on the seed yield the accession notwithstanding. The increase in yield, especially of those plants raised from seeds soaked in $15 \mathrm{mg} / \mathrm{l}$ for 24 and 48 hours, respectively might be implicitly attributed to the effects of the treatment on the vein length, leaf area, number of branches, as well as the number of leaves, which play very crucial roles in photosynthesis (Udensi and Ikpeme; 2012; Udensi et al., 2012).

According to Udensi and Ntui (2013a/b), colchicine affects microtubule depolymerisation through colchicine-tubulin complex formation. Udensi and Ntui (2013a) reported that treatment of pigeon pea seeds with colchicine produced two types of polyploids mixoploids $(2 n+4 n)$ and tetraploids $(4 n)$. They further explained that the mixoploids could either be diploidtriploid $(2 n+3 n)$ or diploid-tetraploid $(2 n+4 n)$. However, if diploid-triploid, the frequency of univalent and trivalents will increase, which will obviously affect the pairing behaviour. This undoubtedly may lead to sterility and impaired seed production (Pandit et al., 2011; Acquaah, 2007; Chen et al., 2007; Dhawan and Lavania, 1996). The major focus of mutation breeding is polyploidy production, especially tetraploids. The understanding is that they produce gametes that are balanced as well as functional (Comai, 2005) as they display heterosis with the resultant positive effect on growth, yield and adaptation. The fact that plants raised from seeds soaked in $15 \mathrm{mg} / \mathrm{l}$ of colchicine for 48 hours did better than those for 72 hours may be accounted for as earlier reported by Udensi and Ntui (2013a) that tetraploids rather than mixoploids are mostly favoured at 48 hours. It is important that mention be made to the fact that auto-tetraploids are usually associated with some degree of seed sterility hence are good for vegetative propagated crops though winged bean is rather seed propagated.

It might be very important to mention here that mutation induction in crop plants becomes successful if the trait(s) so affected is stable along generations. The implication is that it might be rather speculative to assume that the induction in the present study had resulted in improvement of both yield and yield-related traits. Another critical point to be mentioned is that unlike other legumes such as cowpea and pigeon pea whose major aim during breeding is to increase seed yield, winged bean has been reported to be a "supermarket" as all its parts are edible. What it does suggest is that the improvement on the number of leaves and flowers produced by the plants is in the right direction as it will result in the holistic breeding of the crop.

\section{CONCLUSION}

Exposing winged bean seeds to $15 \mathrm{mg} / \mathrm{l}$ of colchicine for 24 and 48 hour duration gave encouraging results and should be considered for further tests and exploitation. 


\section{REFERENCES}

Acquaah, G., 2007. Principles of Plant Genetics and Breeding. Blackwell Publishing Ltd. Malden.

Anon., 1981. The winged bean. A high-protein crop for the tropics. (2nd Edition) National Academy Press, Washington DC, 46.

Boureima, S., Diouf, M., Silme, R. S., Diop, T., Vandamme, P and Cagirgan, M. I., 2009. Radiosensitivity of African sesame cultivars to gamma-rays. Turkish Journal of Field Crops 14(2): 181-190.

Brisibe, E. A., Udensi, O., Ntui, V. O., Otu, P. A and Chukwurah, P. N., 2011. Sensitivity of some quantitative and yield characters of Egusi melon (Colocynthis citrullus L.) to treatment with microtubule inhibitors AFr. J. plants sci; 5:759766.

Chen, L., Lou, Q., Zhuang, Y., Chen, J., Zhang, X and Wolukau, J. N., 2007. Cytological diploidization and rapid genome changes of the newly synthesized allotetraploids cucumis x hytivus. Planta, 225: 603-614.

Ciftci, C. Y., Turkan Divanli, A. K., Khawar, M., Atak, M and Ozcan, S., 2006. Use of gamma rays to induce mutations in four pea (Pisum sativum L.) cultivars. Turk. J. Biol., 30: 29-37.

Comai, L., 2005. The advantages and disadvantages of being polyploidy. Nature Rev. Genet., 6:836846.

Dhawan, O. P and Lavania, U. C., 1996. Enhancing the productivity of secondary metabolites via induced polyploidy. Euphytica, 87:81-89.

Gaeta, R. T., Pires, J. C., Iniguez-Luy, F., Leon, E and

Osborn, T. C., 2007. Genomic changes in resynthesized Brassica napus and their effect on gene expression and phenotype. Plant Cell. 19(11): 3403-3417

Khan, S and Al-Qurainy, F., 2009. Mutagenic effects of sodium azide and its application in crop improvement. World Appl. Sci. J., 6: 1589-1601.

Kumar, D. S., Nepolean, T and Gopalan, A., 2003. Effectiveness and efficiency of the mutagens gamma rays and ethyl methane sulfonate on limabean (Phaseolus lunatus L.) Ind. J. Agric. Res., 37: 115-119 Kumar, R. and R.P. Sinha, 2003. Mutagenic sensitivity of lentil genotypes. J. Appl. Biol., 13: 1-5

Mensah, J. K., Akomeah, P. A and Ekpekurede, E. O., 2005. Gamma irradiation induced variation of yield parameters in cowpea [Vigna unguiculata (L) Walp.]. Global J. Pure Applied Sci., 113:327330.
Pandit, M. K., Pooock. M. J. O and Kunin, W. E., 2011. Ploidy inflences rarity and invasiveness in plants. J. Ecol., 99:1108-1115.

Pons, L. M., Millan, W. A and Cepero, G. M. C., 2001. Radio-sensitivity of rice variety Perla. CentroAgricola, 28: 5-8

Sakiroglu, M and Brummer, E. C., 2011. Clarifying the ploidy of some accessions in the USDA alfalfa germplasm collection. Turkish Journal of Botany. 35:509-519

Stoeva, N and Binera, Z., 2001. Psychological response of beans (phaseolus vulares L.) to gamma radiation contamination growth photosynthesis rate and contents of plastid pigments. Journal of environmental protection and ecology 2: 299303.

Toker, C and Cagirgan, M. I., 2004. Spectrum and frequency of induced mutations in chickpea. ICPN, 11: 20-21

Udensi, O and Ikpeme, E. V., 2012. Correlation and Path Coefficient Analyses of Seed Yield and its Contributing Traits in Cajanus cajan (L.) Millsp. American Journal of Experimental Agriculture, 2(3): 351-358.

Udensi, O. U., Ikpeme, E. V., Obu, J. A and Ekpenyong, D. E, 2012. Assessing the mutagenic effects of gamma irradiation on Cajanus cajan (L.) Huth and Vigna unguiculata (L.) Walp landraces using morphological markers. Comunicata Scientiae 3(4): 271-281

Udensi, O. U., Ntia, M. I and Obianwa, C. U., 2014. Optimizing induced mutation technique for the improvement of agronomic traits in pigeon pea [Cajanus cajan (L.) Millsp.] landraces. Comunicata Scientiae 5(3): 267-278

Udensi, O. U and Ntui, V. O., 2013a. Determination by flow cytometry polyploidy inducing-capacity of colchicine in cajanus cajan (L.) millsp. Pakstan journal of biological sciences 16(13): 630-638.

Udensi, O. U and Ntui, V. O., 2013b. Evaluating the Performance of Amiprophos Methyl and $Y$ irradiated Seeds on Growth and Yield Traits of Pigeon Pea. International Journal of Agriculture \& Biology, 15(5): 885-890

Udensi, O., Edu, E. A., Ikpeme, E. V., Ebigwai, J. K and Ekpe, D. E., 2012a. Biometrical evaluation and yield performance assessment of cowpea [Vigna unguiculata (L.) Walp] landraces grown under lowland tropical condition. Int. J. Plant Breed. Genet., 6: 47-53

Udensi, O., Ikpeme, E. V., Edu, E. A and Ekpe, D. E., 2012b. Relationship studies in cowpea [Vigna unguiculata (L.) Walp] landraces grown under humid lowland condition. Int. J. Agric. Res., 7: 33-45 
Udensi, O., Arong, G. A., Obu, J. A., Ikpeme, E. V and

Ojobe, T. O., 2012c. Radio-Sensitivity of Some Selected Landraces of Pulses to Gamma Irradiation: Indices for Use as Improvement and Preservation Techniques. Amer. J. Exp. Agric., 2: $320-335$.

Uma, M. S and Salimath, P. M., 2001, Effects of ionizing radiations on germination and emergence of cowpea seeds. Karnataka J. Agric. Sci., 14: 1063-1064.

Wang, J., Tian, L., Lee, H., Wei, N. E., Jiang, H., Watson, B., Madlung, A., Osborn, T. C., Doerge, R. W., Comai, L., Chen, Z. J., 2006. Genomewide nonadditive gene regulation in Arabidopsis allotetraploids. Genetics. 172(1): 507-517.

Yang, J and Tan, H., 2011. Winged Bean Milk. International Conference on New Technology of Agricultural, May 2011, 814-817. 